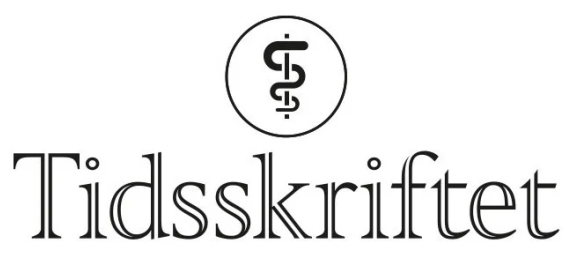

DEN NORSKE LEGEFORENING

\title{
Etter alle smittens regler
}

\author{
ANMELDELSER
}

ANDERS SKYRUD DANIELSEN

Spesialkonsulent, Kreftregisteret

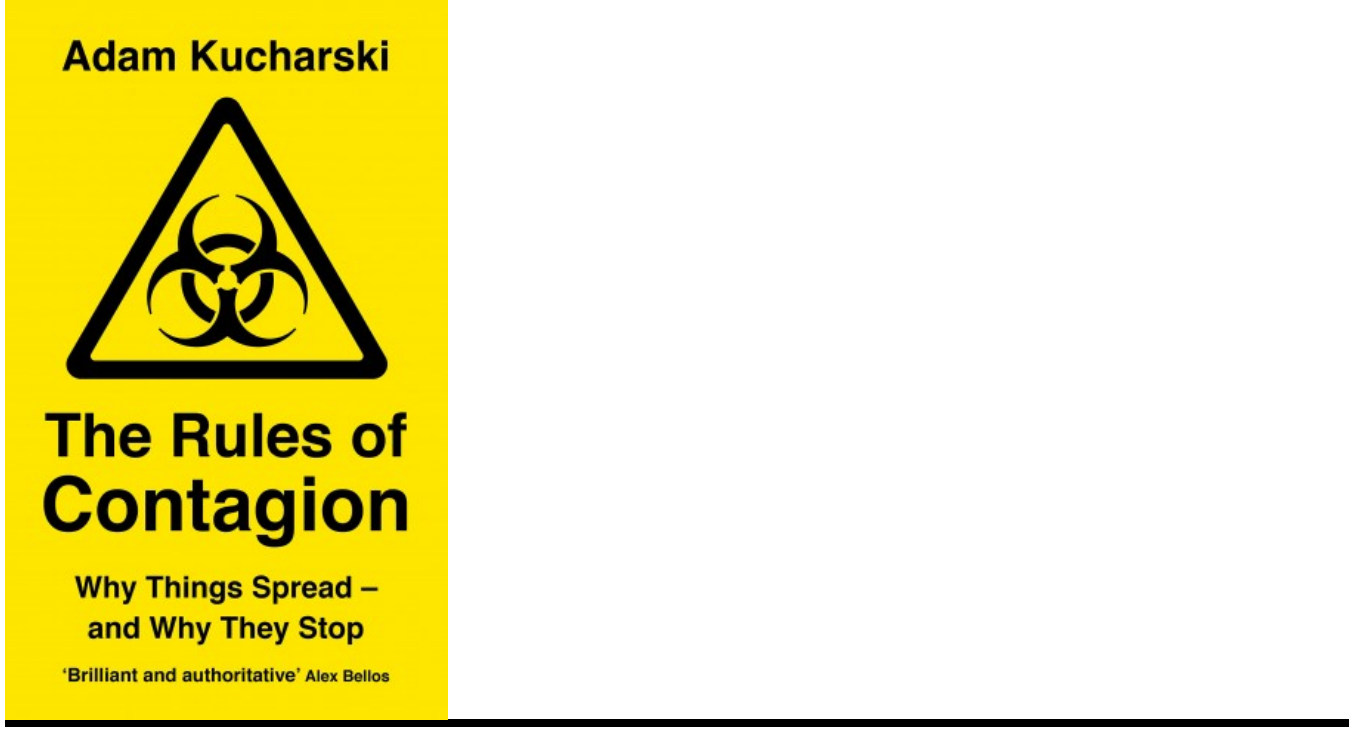

Adam Kucharski

The Rules of Contagion

Why Things Spread - And Why They Stop. 352 s, tab, ill. London: Profile Books, 2020. Pris GBP 17

ISBN 978-1-78816-019-3

Adam Kucharski, epidemiologen kjent fra BBC-serien Pandemic, kunne knapt ha truffet bedre på lanseringstidspunktet for sin siste bok. Som de fleste andre i helsefagene har jeg denne våren og sommeren møtt flere spørsmål av typen «ja, hva tror du om det nye viruset da?». Slike spørsmål er det lettere å svare på etter å ha lest denne boka. I The Rules of Contagion gir Kucharski en god oversikt over smittemodellenes historie, oppbygning og mulige bruksområder, helt uten formler eller programmering. 
Boka begynner med en gjennomgang av Ronald Ross' malariamodell, som av mange anses å være den første smittemodellen. Kucharski går så videre til å vise hvordan Anderson McKendrick og William Kermack utvidet disse ideene til det vi i dag kaller SIR-modellen. SIR står for de tre tilstandene susceptible, infectious, recovered (mottakelige, smittsomme, friske). I modellen lot McKendrick og Kermack pasienter bevege seg fra den første tilstanden til den siste tilstanden over tid gjennom et sett differensiallikninger. Slik skapte de «den epidemiske kurven». Denne kurven, og flere andre kjente figurer fra infeksjonsepidemiologien, som smittenettverk, gjør at leseren kan bli kjent med modellene uten å måtte forstå matematikken bak.

Kucharski er til daglig førsteamanuensis i den matematiske modelleringsgruppa ved London School of Hygiene and Tropical Medicine. Derfor kan han utdype fortellingen om smittemodellene med egne erfaringer fra arbeidet med blant annet ebola i Vest-Afrika og zika i Oseania. Kucharskis prosjekt er derimot ikke begrenset til smittsomme sykdommer. Gjennom boka viser han hvordan smittemodellene kan hjelpe oss til å forstå flere "smittsomme» fenomener i samfunnet, som for eksempel finanskriser, politiske meninger, poster i sosiale media som "går viralt» og datavirus. Til slutt gir forfatteren en oversikt over moderne utvidelser av den klassiske modellen til McKendrick og Kermack, slik som inkludering av fylogenetiske data eller GPS-data.

I en tid der både lekfolk, leger og epidemiologer ønsker å lære mer om hvordan smitte oppfører seg, kunne boka gjerne begrenset seg til å fokusere på sykdom. Likefullt gir de ulike anvendelsene av begreper og konsepter fra infeksjonsepidemiologien en god og lettfattelig innføring i dette lille faget.

Kucharski har rukket å bli en respektert epidemiolog. I TV-opptredener, nyhetssendinger og denne boka viser han også at han er god på populærvitenskapelig formidling. Leserne av The Rules of Contagion vil sitte igjen bedre rustet til å forstå både den pågående pandemien og tolke studier innenfor andre temaer i infeksjonsepidemiologi.

Publisert: 12. oktober 2020. Tidsskr Nor Legeforen. DOI: 10.4045/tidsskr.20.0625

(C) Tidsskrift for Den norske legeforening 2023. Lastet ned fra tidsskriftet.no 26. april 2023. 